"Rafael Campo is one of the most gifted and accomplished younger poets writing in English. More than that, he is a writer engaged in several of the pivotal struggles and issues of our era, and what he has to say about them is 'news that stays news.' "-Marilyn Hacker

"Campo's background and concerns - he writes out of his identity and experience as a gay Cuban American physician - make for a rich field of investigations, and his best work is both passionate and formally accomplished. What the Body Told dives into the difficult, necessary territory of physical love, desire, contagion, illness; such poems are essential to our moment. We need them."-Mark Doty

"Campo is one of the most attractive, interesting and-I can think of no better word-valuable poets of his generation. The news he has to tell is the news we need, and his talent, happily, is equal to his message."-Richard Howard

"[A] virtuoso display. ... Campo is a master of image. ... His poems are revealing and courageous." - Jay A. Liveson, Journal of the American Medical Association

"Campo writes mordant lyrics of dark love that displace trite expectations of what sonnets or canciones should accomplish. His work is devoid of cheap romanticizing." - Jerry W. Ward Jr., Washington Post Book World

"Campo's heartfelt prose is the real thing. He lays himself bare and in the process creates art."-Library Journal 
"I know of no poet writing today with more courage and compassion than Rafael Campo. Like the practicing physician that he is, Campo writes poems that heal artfully-or honestly face the impossibility of healing. Here we find sonnets for the damned, songs for the dying, the insistence on empathy for a prostitute with AIDS on a Boston street corner. There is the unforgiving squint of a mother rejecting her gay son. Yet there is a soaring lyricism in these poems, epiphany and redemption, a celebration of bloodstained, stubborn life as it bursts forth. The poems of Rafael Campo inspire that sharp breath of recognition. He has all my gratitude and admiration.” - Martín Espada, author of Imagine the Angels of Bread

"Extraordinary meditations on illness and the healing power of words." - Lambda Literary Foundation

"Rafael Campo is perhaps our most distinguished physician-poet since William Carlos Williams. . . [His] sense of a common humanity is hard-won against the ugliness, misery, and cruelty that he must confront in his practice."-David Bergman, The Gay and Lesbian Review 
Landscape with Human Figure 



\section{Rafael Campo}

\section{LANDSCAPE WITH HUMAN FIGURE}

Duke University Press Durham and London 2002 
(C) 2002 Rafael Campo

All rights reserved

Printed in the United States of

America on acid-free paper (a)

Designed by C. H. Westmoreland

Typeset in Carter \& Cohn Galliard by

Tseng Information Systems, Inc.

Library of Congress

Cataloging-in-Publication Data

Campo, Rafael.

Landscape with human figure / Rafael Campo.

p. $\mathrm{cm}$.

IS BN 0-8223-2875-5 (acid-free paper) -

ISBN 0-8223-2890-9 (pbk. : acid-free paper)

I. Cuban Americans-Poetry. 2. Medicine-

Poetry. 3. Gay men-Poetry. I. Title.

PS3553.A4883 L36 2002

$8 \mathrm{II}^{\prime} \cdot 54-\mathrm{dc2} \quad 2001047057$

The promotion, marketing, and distribution of this book are supported by a generous grant from the Gill Foundation. 
for my parents, who taught me to love for Jorge, who brought me to life 

Dominion strong is the body's; dominion stronger is the mind's.

-Walt Whitman, Democratic Vistas

And my "medicine" was the thing which gained me entrance to these secret gardens of the self.

—William Carlos Williams, Of Medicine and Poetry 
